\title{
Clinton billed to back US research effort...
}

Washington. President Bill Clinton will speak out in support of his science and technology programmes at an awards presentation at the White House in midOctober, according to his science adviser, thus ending a long silence that had led many observers to question his commitment to the programmes.

Jack Gibbons, the science adviser, promised last week that the administration will defend its planned technology programmes "to the death". At the same time, however, he hinted that it is close to giving up hope of getting any new money for one of them, the Advanced Technology Program (ATP).

University representatives and science policy experts in Washington are concerned that, as the budget clash between the administration and the Congress approaches its climax, Clinton has publicly concentrated on defending education and some social programmes. They fear that he will fail to oppose Congress's proposed cuts in science and technology effectively.

The main cuts proposed by the Republican Congress so far are in the ATP, other assistance for industrial development, energy and transportation research, and science connected with global warming and the environment.

At a briefing with Laura Tyson, Clinton's economics adviser, Gibbons cited "Japan's plans to double its investment in research" as the main reason for opposing the proposed cuts. Gibbons strongly attacked

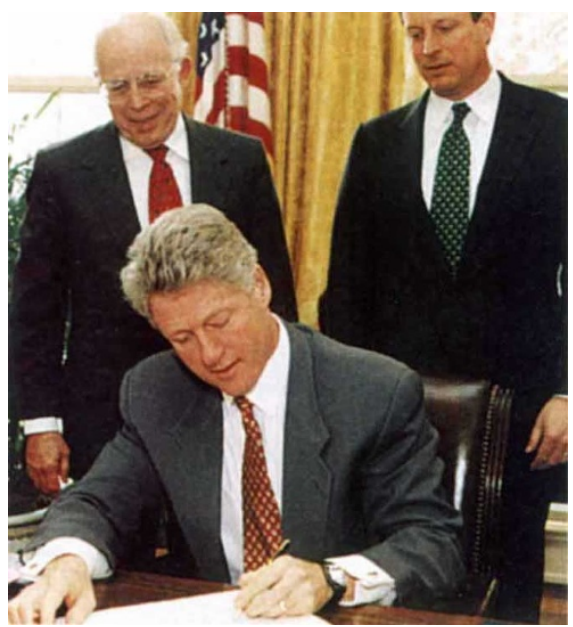

All hands on deck: Clinton is scheduled to back the efforts of Gibbons (top left).

the cuts in ATP funding and in environmental research, including NASA's Mission to Planet Earth programme (see page 191).

Asked why Clinton has not publicly responded to criticisms of these proposed cuts, Gibbons said that the president "had a lot on his plate" at the moment. "We wouldn't be saying these things if we weren't fully assured of the president's views," Gibbons added. "In mid-October he's planning a major address on science and technology issues." The address will take place at the presentation of the National Science and Technology Medals, an event always held at the White House, but only occasionally attended by the incumbent president.

Congress had been due to present its budget bills by 1 October, but is running a little late, so the address will come just as Clinton is entering the crucial phase of budget negotiations. Unsurprisingly, Gibbons and Tyson declined to say which programmes he will defend. "These bills are not going to end up as they are now," declared Tyson.

But Gibbons did suggest that the administration is likely to retreat on ATP, the most contentious single issue in the science and technology budget, for which Clinton has requested $\mathbf{\$ 5 0 0}$ million and the House of Representatives has appropriated nothing.

He said the president would argue for "saving a portion of the ATP, and at least fulfilling the commitments that have already been made". His words left the clear impression that the White House is moving closer to the position of the Senate, which appropriated $\$ 75$ million to wrap up existing ATP projects. Colin Macilwain

\section{... as NIH hopes for the best out of coming budget crunch}

Washington. A US Senate committee has voted to give the National Institutes of Health (NIH) a \$300-million boost over this year's funding, equivalent to a growth of 2.7 per cent at a time when many other programmes are being heavily reduced.

But the committee's panel's efforts are overshadowed by a threat from President Bill Clinton to veto the broader bill in which the NIH budget is included and halt the entire budget process if Republicans do not begin negotiations over their proposed cuts in other social programmes.

One possible outcome could be the temporary closure of all government agencies including the $\mathrm{NIH}$ - on 1 October, the beginning of the new fiscal year, if no agreement is reached by then. That could lead to delays in the receipt by NIH-funded scientists of next year's research grants; at present, 400 review groups are scheduled to meet in October to discuss such awards, which are usually made in December.

The bill approved by the Senate Appropriations Committee, and likely to be adopted by the full Senate later this week, would provide $\$ 11.6$ billion for NIH in fiscal year 1996. This represents a 2.7 per cent increase over the funds received by the biomedical research agency in the current year, and contrasts with both the 5.7 per cent increase proposed by the House of Representatives and a 4.5 per cent increase proposed by the president in his initial budget request.

The House of Representatives and the Senate will work out the differences in their versions of the bill - which covers appropriations for the departments of Labor, Health and Human Services (HHS), and Education - in a conference committee

If the committee agrees to a compromise figure of 4.2 per cent, this would be welcomed by the community as the best that could be expected in the circumstances. "That would be a very good number," says Dave Moore, of the American Association of Medical Colleges.

But what happens after the conference is anyone's guess. Clinton has threatened to veto the bill, not only because its proposed funding for education is too low, but because he feels that more money should be given to the whole budget for labour, education, health and other social programmes.

The Senate bill, drafted by the moderate Arlen Specter (Republican, Pennsylvania), chair of the Labor, HHS and Education appropriations subcommittee, is missing most of the legislative directives that had been included in the House bill. These include a ban on embryo research funded by the NIH, and the elimination of separate funding for the Office of AIDS Research. But Bob Livingston (Republican, Louisiana), chair of the House Appropriations Committee, has said he will push to restore the restrictions in conference.

The Senate bill puts more emphasis on education and social services than the House bill, leaving less money for NIH. The National Cancer Institute, the National Center for Human Genome Research, the National Institute of Allergy and Infectious Diseases, the National Center for Research Resources and the Library of Medicine receive the largest increases from the Senate, in each case more than 4.6 per cent.

The Senate bill recommends $\$ 1.38$ billion for the Office of AIDS Research, a \$53-million increase over the 1995 level but \$19 million less than the president's request.

The NIH has asked that a few thousand of its 15,000 employees should be allowed to attend to patients, animals and cell lines in the event of a shutdown. Such an exception is normally made only for "essential" employees.

Adrianne Appel 